\title{
PENGARUH KONSENTRASI KALIUM FEROSIANIDA TERHADAP PEWARNAAN Fe PADA SUMSUM TULANG
}

\section{THE EFFECT OF POTASSIUM FERROCYANIDE CONCENTRATION ON BONE MARROW Fe STAINING}

\author{
Khoiriyatunnisa $^{1}$, Stalis Norma Ethica ${ }^{2}$, Budi Santosa ${ }^{1}$ \\ ${ }^{1}$ Program Studi D IV Analis Kesehatan, Fakultas Ilmu Keperawatan dan Ilmu Kesehatan, Universitas \\ Muhammadiyah Semarang \\ ${ }^{2}$ Program Studi D III Analis Kesehatan, Fakultas Ilmu Keperawatan dan Ilmu Kesehatan, \\ Universitas Muhammadiyah Semarang \\ Korespondensi: Khoiriyatunnisa. Email: nisa_annada@yahoo.com
}

\begin{abstract}
ABSTRAK
Pemeriksaan sumsum tulang merupakan uji diagnostik standar emas untuk penilaian cadangan zat besi di dalam tubuh, sehingga pemeriksaan ini dianggap pentingPemeriksaan cadangan besi sumsum tulang dalam prakteknya, ada beberapa variasi konsentrasi larutan kalium ferosianida $\left(\mathrm{K}_{4} \mathrm{Fe}(\mathrm{CN})_{6} \cdot 3 \mathrm{H}_{2} \mathrm{O}\right)$ yang digunakan. Faktanya, kalium ferosianida merupakan zat beracun yang berdampak buruk pada kesehatan jika terpapar pada konsentrasi tinggi. Di sisi lain, pengaruh konsentrasi kalium ferosianida terhadap kualitas hasil pewarnaan Fe belum pernah dilaporkan. Penelitian ini bertujuan untuk mengetahui pengaruh konsentrasi kalium ferosianida terhadap kualitas hasil pewarnaan Fe berdasarkan interpretasi visual sebagai bagian dari pemeriksaan sumsum tulang. Secara lebih khusus, penelitian ini bertujuan untuk menentukan konsentrasi kalium ferosianida terendah dengan hasil kualitas pewarnaan Fe dengan interpretasi baik. Objek penelitian ini adalah sampel sumsum tulang pasien terdiagnosis anemia. Kemudian sampel diperiksa dengan pewarnaan Fe berbagai variasi konsentrasi kalium ferosianida, yaitu: $1 \%, 2 \%, 3 \%, 4 \%$, dan 5\% b/v (artinya b/v apa? Jangan menyingkat sebelum diberikan kepanjangannya). Hasil penelitian menunjukkan bahwa terdapat perbedaan yang signifikan pada hasil interpretasi tingkat cadangan besi akibat kualitas hasil pewarnaan yang berbeda akibat pengaruh variasi konsentrasi ferosianida dengan nilai uji signifikansi 0,00 $(p<0,05)$ berdasarkan uji statistik Fisher. Dari hasil penelitian ini, konsentrasi kalium ferosianida yang paling direkomendasikan untuk pemeriksaan cadangan besi dalam sumsum tulang adalah $2 \% \mathrm{~b} / \mathrm{v}$, karena konsentrasi kalium ferosianidanya tidak terlalu tinggi namun menghasilkan kualitas penafsiran terbaik.
\end{abstract}

Kata kunci: Pewarnaan Besi, Cadangan Besi Tubuh, Kalium Ferosianida, Sumsum Tulang

\begin{abstract}
Bone marrow examination is one of the most crucial diagnostic test considered as gold standard for the assessment of iron reserves in the body. In practice, there has been variation of potassium ferocyanide $\left(\mathrm{K}_{4} \mathrm{Fe}(\mathrm{CN})_{6} \cdot 3 \mathrm{H}_{2} \mathrm{O}\right)$ concentrations used in the iron staining step of the exam by medical laboratory workers. In fact, ferrocyanide is a toxic substance exposing health risks if used in high concentration. Yet, there have been no reports about the effect of ferrocyanide concentration on the quality of Fe staining results. This study aims to determine the effect of potassium ferrocyanide concentration on Fe staining result quality by visual interpretation as part of bone marrow examination. In more particular, it determines the lowest possible concentration (lowest toxicity) of ferrocyanide that could result in acceptable quality of Fe staining results. Objects of this study were bone marrow samples of patients diagnosed with anemia, which later examined by Fe staining using ferrocyanide at varied concentrations of 1, 2, 3, 4, and 5\% b/v, respectively. Results indicated that there was significant difference on interpretation quality of iron reserves due to variation of ferrocyniade concentrations with significance test value of $0.00<0.05$ based on Fisher's test statistic. Results showed that the most recommended concentration of potassium ferrocyanide, which is not too high but resulting in the best possible interpretation quality of iron reserves on bone marrow is $2 \% \mathrm{~b} / \mathrm{v}$.
\end{abstract}

Keywords: Fe Staining, Iron Reserves, Potassium Ferrocyanide, Bone Marrow 


\section{PENDAHULUAN}

Saat ini pemeriksaan sumsum tulang merupakan salah satu uji diagnosis yang paling diperhitungkan dalam menegakkan diagnosis kelainan hematologi. Menurut Adewoyin et al. (2015) pemeriksaan sumsum tulang merupakan prosedur uji yang mampu memberikan tingkat hasil informasi pemeriksaan yang tinggi untuk mendiagnosis atau mengevaluasi kelainan hematologi.

Terkait kelainan hematologi, penyakit anemia defisiensi besi merupakan kelainan hematologi yang paling sering ditemukan. Di negara maju, sepertiga kasus anemia merupakan kasus defisiensi besi (Kassebaum, 2016) Peningkatan jumlah kasus yang lebih tinggi terjadi di negara berkembang (Bain, 2001). Menurut World Health Organization (WHO) (2013) prevalensi anemia dunia berkisar 40-88 \%.

Kelainan kadar besi ( $\mathrm{Fe})$ dapat didiagnosis dengan menentukan kadar besi yang tersimpan di dalam tubuh. Hal ini dapat dilakukan melalui pemeriksaan hemoglobin, HCT, indeks eritrosit (MCV, MCH, dan MCHC), apus darah tepi, kadar besi serum, serum transferin, serum feritin, dan sumsum tulang (Bakta, 2006; Santosa, 2010).

Pemeriksaan secara mikroskopis terhadap sediaan sumsum tulang merupakan "gold standard" untuk penilaian cadangan besi di dalam tubuh. Pewarnaan Fe dengan deteksi hemosiderin menggunakan metode Perl's aspirat sumsum tulang dianggap sebagai standar emas dari tes lain untuk menilai defisiensi zat besi dan deplesinya (Smith et al. 2005).

Pewarnaan Fe metode Perl's menggunakan pewarna kalium ferosianida akan memberikan warna biru pada cadangan besi yang tersimpan. Penggunaan kalium ferosianida dalam konsentrasi tertentu dalam pewarnaan ini bertujuan menghasilkan pewarnaan yang baik dan memudahkan untuk mengidentifikasi cadangan besi. Pewarnaan Fe dengan metode Perl's merupakan proses reaksi antara hemosiderin yang berpigmen emas dengan kalium ferosianida yang menghasilkan endapan ferri ferrosianida yang berwarna biru, dan dapat diamati secara mikroskopis (Mescher, 2012).

Kation fero $\left(\mathrm{Fe}^{2+}\right)$ dalam senyawa $\mathrm{K}_{4} \mathrm{Fe}(\mathrm{CN})_{6} \cdot 3 \mathrm{H}_{2} \mathrm{O}$ memiliki kemampuan mengikat 6 ligan seperti logam transisi yang lain seperti $\mathrm{Co}^{2+}$
(Ethica \& Setiaji, 2002). Berdasarkan informasi data keselamatan Thermo Electron Corporation (2003) larutan kalium ferosianida memiliki sifat bahaya karena dapat menyebabkan kulit dan mata dan iritasi pernapasan (MSDS, 2010).

Menurut Prosedur Polysciences inc. (2006), pewarnaan untuk diagnosis besi disarankan menggunakan larutan kalium ferosianida dengan konsentrasi $4 \quad \% \quad b / v$. Namun berdasarkan observasi di lapangan, pada petunjuk di rumah sakit-rumah sakit dan prosedur lainnya yang ada di klinik dan puskesmas untuk pewarnaan sediaan sumsum tulang banyak digunakan konsentrasi kalium ferosianida yang berbeda-beda. Karena hal tersebut, menarik untuk diketahui bagaimana pengaruh adanya variasi konsentrasi pewarna kalium ferosianida terhadap hasil pewarnaan besi dalam sediaan sumsum tulang. Pada dasarnya, penggunaan konsentrasi yang lebih rendah diharapkan dapat menjadi alternatif pilihan ekonomis yang bisa digunakan untuk pewarnaan besi pada sumsum tulang. Namun demikian perlu diuji apakah terdapat pengaruh kosentrasi larutan kalium ferosianida yang lebih rendah $(1,2,3$, dan $4 \% \mathrm{~b} / \mathrm{v}$ ) jika dibandingkan dengan konsentrasi tertinggi $5 \% \mathrm{~b} / \mathrm{v}$ dalam hasil pewarnaan $\mathrm{Fe}$. Berdasarkan kondisi tersebut perlu dilakukan penelitian mengenai pengaruh konsentrasi kalium ferosianida terhadap kualitas hasil pewarnaan Fe.

\section{METODE}

\section{Alat dan bahan}

Dalam penelitian ini sampel yang digunakan berupa aspirat sumsum tulang. Alat dan bahan yang digunakan adalah gelas objek, pipet tetes, rak pewarna, chamber, waterbath, gelas beaker, neraca analitik, dan mikroskop optik. Bahan yang digunakan adalah kalium ferosianida, $\mathrm{HCl}$, metanol, safranin, EDTA 10\% (semua dari Merck) dan aquades.

\section{Prosedur penelitian}

Jenis penelitian ini adalah penelitian eksperimen dengan rancangan post test only control group. Pengambilan aspirasi sumsum tulang dilakukan sesuai dengan prosedur yang dilakukan oleh Gandasoebrata (2013) yang meilbatkan tahap disinfeksi, anastesi, pemasukan jarum, pengisapan sumsum, penutupan luka dengan plester, serta penyimpanan dalam tabung berisi antikoagulan 
EDTA 10\%. Pembuatan sediaan tulang dilakukan dengan metode Spread menggunakan spreader (Gandasoebrata, 2013).

Pembuatan reagen kalium ferosianida dilakukan mengikuti prosedur yang dikeluarkan oleh Bio Protokol (2012). Selanjutnya pewarnaan Fe yang diikuti pemeriksaan secara makroskopis dan pencatatan hasil dilakukan sesuai metode yang telah dikembangkan oleh Bain (2001).

Interpretasi hasil pewarnaan $\mathrm{Fe}$ yang dilakukan dalam penelitian ini mengikuti standar gradasi yang telah ditetapkan oleh Gale et al. (1963) dengan penjabaran sebagaimana yang ditampilkan pada Tabel 1.

Tabel 1. Gradasi histologi status besi sumsum tulang menurut Gale et al. (1963)

\begin{tabular}{|c|c|c|}
\hline Tingkat & Tampak & Keterangan \\
\hline 0 & Tidak ada & $\begin{array}{l}\text { Tidak tampak partikel besi } \\
(\mathrm{x} 1000)\end{array}$ \\
\hline 1 & $\begin{array}{l}\mathrm{S} \text { a } \mathrm{n} g \text { a } \mathrm{t} \\
\text { sedikit }\end{array}$ & $\begin{array}{l}\text { Tampak partikel besi yang kecil } \\
(\mathrm{x} 1000)\end{array}$ \\
\hline 2 & Sedikit & $\begin{array}{l}\text { Tampak partikel besi yang kecil } \\
\text { dan sedikit (x100) }\end{array}$ \\
\hline 3 & Sedang & $\begin{array}{l}\text { Tampak banyak partikel besi } \\
(\mathrm{x} 100)\end{array}$ \\
\hline 4 & $\begin{array}{l}\mathrm{S} \text { a } \mathrm{n} g \text { a } \mathrm{t} \\
\text { sedang }\end{array}$ & $\begin{array}{l}\text { Tampak partikel besi } \\
\text { bergerombol di seluruh fragmen } \\
(\mathrm{x} 100)\end{array}$ \\
\hline 5 & Berat & $\begin{array}{l}\text { Tampak partikel besi dan } \\
\text { membentuk gerombol besar } \\
\text { pada fragmen }\end{array}$ \\
\hline 6 & $\begin{array}{l}\mathrm{S} \text { a } \mathrm{n} g \text { a } \mathrm{t} \\
\text { berat }\end{array}$ & $\begin{array}{lcr}\text { Tampak partikel } & \text { besi } \\
\text { bergerombol } & \text { besar } & \text { dan } \\
\text { mengaburkan } & \text { warna } & \text { sel di } \\
\text { fragmen } & & \end{array}$ \\
\hline
\end{tabular}

Data penelitian yang diperoleh kemudian diuji dengan analisis Fisher's exact dan dibuat narasi deskriptifnya.

\section{HASIL DAN PEMBAHASAN}

Hasil pewarnaan sampel dikatakan positif mengandung besi (tingkat 1-6) apabila terdapat minimal 7 partikel besi, dikatakan negatif (tingkat 0) apabila tidak terdapat partikel besi atau partikel besi kurang dari 7 partikel (Bain et al. 2001).

Hasil uji menunjukkan nilai-nilai Asymp Sig $0,00<0,05$ (lebih kecil dari 0,05 ) yang berarti bahwa terdapat pengaruh variasi konsentrasi kalium ferosianida terhadap hasil pewarnaan $\mathrm{Fe}$ pada sumsum tulang.

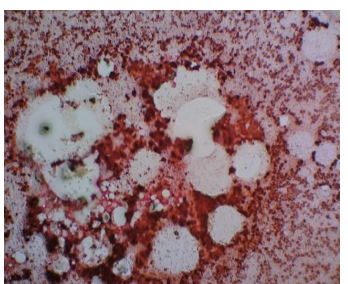

A.

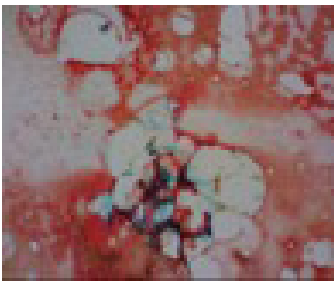

C.

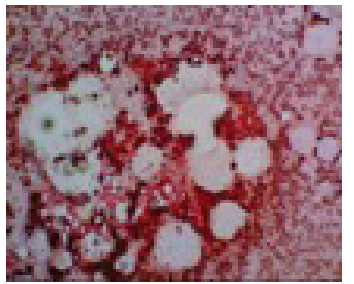

E.

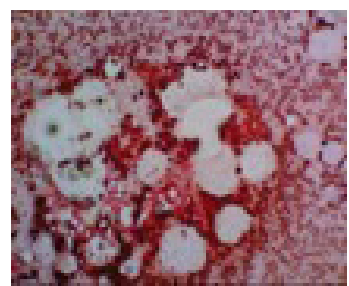

B.

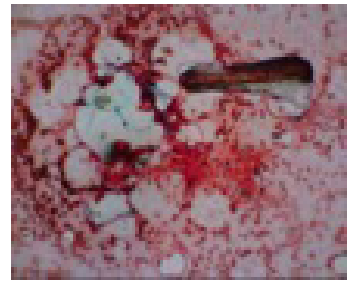

D.

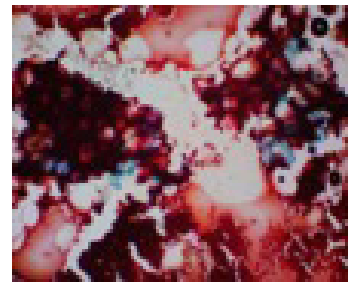

F.
Gambar 1. Hasil pewarnaan Fe pada sampel sumsum tulang menggunakan larutan ferosianida dengan konsentrasi: A. $1 \%$ b/v. B. $2 \%$ b/v. C. $3 \%$ b/v. D. $4 \%$ b/v. E. $5 \% \mathrm{~b} / \mathrm{v}$.

Berdasarkan Gambar 1, hasil pengamatan mikroskopis pada pewarnaan Fe sumsum tulang dengan konsentrasi $1 \%(\mathrm{~b} / \mathrm{v})$ dihasilkan pewarnaan Fe yang kurang maksimal karena warna partikel besi kurang terwarnai dengan baik, warna biru tidak terlihat jelas dalam perbesaran $100 \mathrm{x}$, dan baru terlihat jika menggunakan perbesaran 1000x karena itu penilaian yang diberikan adalah tingkat 1. Pada penggunaan konsentrasi 2 dan 3\% (b/v) diperoleh hasil pewarnaan Fe yang baik. Artinya secara mikroskopis partikel besi berwarna biru, sel-sel selain partikel besi berwarna merah, dan lemak berwarna bening pada konsentrasi ini penilaian cadangan besi masing-masing berada pada tingkat 3 yakni tampak banyak partikel besi pada perbesaran 100x.

Secara makroskopis hasil pewarnaan $\mathrm{Fe}$ sumsum tulang pada sediaan konsentrasi 4 dan 5\% $(\mathrm{b} / \mathrm{v})$ terlihat gelap, tampilan fragmen berwarna biru pekat dengan kombinasi warna merah sebagai counterstain. Hasil pengamatan cadangan besi pada kosentrasi 4 dan $5 \%(\mathrm{~b} / \mathrm{v})$ menunjukkan cadangan besi masing-masing pada tingkat 5 , cadangan besi terlihat biru pekat dan bergerombol. 
Data yang diperoleh dari hasil yang ditampilkan pada Gambar 1 dan telah dibuat gradasi histologinya sesuai Tabel 1 kemudian diuji dengan uji Fisher probability exact dan hasilnya ditunjukkan pada Tabel 2. Uji Fisher probability exact merupakan uji non parametrik yang sesuai dengan karakteristik data yang diperoleh pada penelitian ini

Tabel 2. Hasil Fisher's exact test

\begin{tabular}{ccc}
\hline $\begin{array}{c}\text { Fisher's } \\
\text { exact }\end{array}$ & Value & Exact sig 2- sided \\
\cline { 2 - 3 } & 33.872 & .000 \\
\hline
\end{tabular}

Penggunaan variasi kalium ferosianida untuk pemeriksaan Fe dengan metode Perl's pada sumsum tulang dilakukan agar dapat mengetahui konsentrasi optimal untuk mendiagnosis simpanan besi di dalam sumsum tulang. Berdasarkan hasil analisis fisher's exact terdapat pengaruh variasi konsentrasi kalium ferosinanida terhadap hasil pewarnaan $\mathrm{Fe}$ pada sumsum tulang.

Penggunaan konsentrasi $1 \%(\mathrm{~b} / \mathrm{v})$ pada pewarnaan Fe dengan metode Perl's pada sampel sumsum tulang terdiagnosis anemia, memberikan hasil pewarnaan sesuai syarat hasil dari pewarnaan Fe. Namun demikian, hasil pengamatan mikroskopis akan memberikan perbedaan interpretasi hasil karena pigmen biru yang terbentuk tidak terbentuk sempurna, sehingga sangat sedikit memberikan gambaran hasil pemeriksaan simpanan besi (tingkat 1). Menurut situs patologi Medlab.com penggunaan konsentrasi zat warna yang rendah menyebabkan semakin sedikit zat warna yang terikat dengan komponen jaringan. Hal ini terbukti dengan penelitian ini, karena konsentrasi zat warna kalium ferosianida yang digunakan rendah maka pigmen biru yang terbentuk pucat.

Menurut Hayat (1993) untuk mencapai tingkat pewarnaan optimal dengan waktu yang singkat bergantung pada konsentrasi dan proses pewarnaan dengan konsentrasi larutan yang lebih besar. Dalam penelitian ini, penggunaan konsentrasi ferosianida sebesar 2 - 3\% (b/v), kriteria pewarnaan $\mathrm{Fe}$ terlihat sudah memenuhi syarat antara lain adanya warna merah pada sel sebagai counterstain dan paling penting adalah terbentuknya warna prussian blue (pigmen biru) sebagai bentuk simpanan besi di dalam tubuh dapat diamati dengan jelas (Cheles, et al. 2004). Pengamatan pada pewarnaan $\mathrm{Fe}$ dengan konsentrasi kalium ferosianida $2-3 \%(\mathrm{~b} / \mathrm{v})$ ternyata memberikan interpretasi hasil yang sama yakni cadangan besi pada tingkat 3. Namun demikian, penggunaan konsentrasi $2 \%$ b/v akan lebih menguntungkan dari segi biaya dan resiko toksisitas penggunaan reagen ferosianida. Pengunaan konsentrasi kalium ferosianida $2 \% \mathrm{~b} / \mathrm{v}$ untuk pewarnaan metode Perl's ini dilakukan dalam metode pemeriksaan sumsum tulang yang dilakukan oleh Ochai dan Kolhatar (2008).

Penggunaan konsentrasi kalium ferosianida $4-5 \%(b / v)$ hasil pengamatan memberikan hasil penilaian cadangan besi yang berbeda, pigmen biru bergerombol dan intensitas pigmen biru tampak pekat biru tua hingga hitam yang akan mengaggu pengamatan karena warna yang dihasilkan tidak sesuai dengan ciri pewarnaan besi metode Perl's.

Banyaknya petunjuk prosedur kerja pewarnaan $\mathrm{Fe}$ yang beredar di lapangan dengan menggunakan konsentrasi kalium ferosianida yang berbeda seperti, prosedur kerja pewarnaan Fe oleh Sigma Aldrich (2014) yang menggunakan konsentrasi kalium ferosianida 4\% (b/v). Hal ini dapat diminimalisir penggunaan zat kalium ferosianida dengan menggunakan konsentrasi 2 - 3\% (b/v) karena dilihat dari hasil pewarnaan, konsentrasi 2 - 3\% (b/v) telah memberikan hasil pewarnaan yang jelas sesuai dengan ciri pewarnaan Fe.

Penggunaan kalium ferosianida pada konsentrasi tertentu, ditujukan untuk mendapatkan hasil pewarnaan yang baik, sesuai standar teknis dan meminimalkan paparan toksik dari larutan. Standar utama sebuah larutan adalah harus memiliki kemurnian tinggi yang dapat dilarutkan (IUPAC, 1987). Kalium ferosianida merupakan larutan yang memiliki label A.C.S (American Chemical Society) yang berarti larutan ini termasuk dalam kategori larutan kimia dengan kemurnian tertinggi yang ditetapkan oleh American Chemical Society (ACS). Kualitas kalium ferosianida yang digunakan harus diteliti mutunya dan dilihat tanggal kadaluarsa. Larutan yang sudah kadaluarsa akan mempengaruhi kualitas larutan dan akan menghasilkan hasil pewarnaan yang tidak baik (OMCL, 2012).

Pewarnaan Fe merupakan jenis pemeriksaan sitokimia di laboratorium yang dapat dilakukan dengan metode manual maupun otomatis. Penggunaan alat otomatis salah satunya dapat menggunakan alat MATRX Ultra yang dapat digunakan sebagai alat otomatis pewarnaan histokimia dan sitokimia (BioGenex, 2016). 
Penggunaan metode manual sebagai pilihan pemeriksaan mengharuskan adanya ketelitian dalam pemakaian kualitas larutan, proses pewarnaan dan pengamatan, agar hasil pemeriksaan akurat. Selain itu, buku tuntunan Good Laboratory Practice (GLP) (2010) menambahkan dalam pelaksanaan teknis pemeriksaan laboratorium harus memiliki nilai ekonomis dan keselamatan dalam bekerja.

\section{SIMPULAN}

Penggunaan konsentrasi zat kalium ferosianida yang lebih rendah dapat menjadi pilihan alternatif pelaksanaan teknis yang efektif, efisien dan aman bagi petugas labaratorium sehingga dapat menghemat biaya pemakaian reagen dengan hasil pemeriksaan yang tetap akurat sehingga tetap menjaga kepuasan konsumen atau pasien.

\section{PERSANTUNAN}

Ucapan terima kasih disampaikan kepada para dosen pembimbing, orang tua, rekan-rekan mahasiswa dan semua pihak yang telah memberikan motivasi dan semangat dalam menyelesaikan manuskrip jurnal ini.

\section{DAFTAR PUSTAKA}

Adewoyin, A. S., Ezire, E. S., Adeyemi, O., Idubor, N. T. and Edewor-okiyo, D. O. 2015. Bone Marrow Aspiration Cytology Studies In A Tertiary Hospital, Nigeria: A Serie Of 88 Cases. Annals of Pathology and Laboratory Medicine. Volume 2: A108-A114

Bain, B. J. 2001. Bone Marrow Trephine Biopsy. Journal Clin Pathol. (54): 657-663.

Bain, B. J., Clark, D. M., Lampert, I. A., Wilkins, B. S. 2001. Bone Marrow Pathology - Third Edition. Australia: Blackwell Science Ltd.

Bakta, I. M. 2006. Hematologi Klinik Ringkas. Jakarta: EGC.

Polysciences, www.polysciences.com 3 Juli 2017 (18.10).

Bio-protocol, www.bio-protocol.org 3 Juli 2017 (22.20).

BioGenex. www.biogenex.com. 30 Oktober 2017 (10.05).

Cheles, M., Couture, R., Holliday, J. M., Smith, S., Stanforth, D. A. 2004. Guide To Special Stain. California USA : DakoCytomation.

Ethica, S.N. and Setiaji, A.B., 2002. Simulasi Monte Carlo sistem Co2+dalam air melibatkan potensial badan tiga (Master thesis, [Yogyakarta]: Universitas Gadjah Mada).

Gale, E., Torrence, J., Bothwell, T. 1963. The quantitative estimation of total iron stores in human bone marrow. Journal Clin Invest. (42):1076-82.

Gandasoebrata, R. 2013. Penuntun Laboratorium Klinik. Jakarta: Dian Rakyat.

Hayat, M. A. 1993. Stains and Cythochemical Methods. New York. Plenum Press.

IUPAC, P.P., Everett, D., Haul, R., Moscou, L., Pierotti, R., Rouquerol, J. and Siemieniewska, T., 1985. Pure Appl. Chem, 57, p.603.

Material Safety Data Sheet (MSDS) Potassium Ferrocyanide Solution. 2010. Katalog Nomor 184. Canada: Leica Mucrosystems Canada Inc.

Mescher, A. L. 2012. Histologi Dasar Junqueira Teks Dan Atlas. Edisi 11. Jakarta: EGC.

Ochai, J dan A. Kolhatar. 2008. Medical Laboratory Science Theory and Practice.. New Delhi: Tata McGraw-Hill Publsihing.

Santosa, B., 2010. Differential Counting Berdasarkan Zona Baca Atas Dan Bawah Pada Preparat Darah Apus. In Prosiding Seminar Nasional \& Internasional.

Smith, S. E. S., Hughes, D. A., Bain, B. J., 2005. Are Routine Iron On Bone Marrow Trephine Biopsy Specimens Necessary?. Journal Clin Pathol (58): 269-272. 